\title{
Drug Addiction and the Practice of Public Health in Late Imperial and Early Soviet Russia
}

\section{P. A. Vasilyev}

For citation: Vasilyev P. A. Drug Addiction and the Practice of Public Health in Late Imperial and Early Soviet Russia. Vestnik of Saint Petersburg University. History, 2018, vol. 63, issue 4, pp. 1100-1119. https://doi.org/10.21638/11701/spbu02.2018.407

The relatively short period from 1914 to 1932 witnessed a radical change in the attitudes of both governmental authorities and professional communities towards drugs and addiction. Before the First World War, Russians could easily buy cocaine or heroin at a pharmacy, medical science did not view addiction as a serious social problem. There was practically no government regulation or legislation concerning recreational drugs. By the early 1930s, however, the market of recreational drugs had been heavily regulated, drug sale had been criminalized, and physicians and criminologists had begun to label drug addicts as bourgeois, degenerate, or otherwise socially anomalous people who should be sent to special camps. An important turning point occurred in late 1924, when Soviet authorities issued two decrees that provided a legal definition of criminal drug sales, signaling the start of a more intensive struggle against drug abuse. This paper examines the social practice of late Imperial and early Soviet public health in order to evaluate the evolution of "in-the-field" medical approaches towards opiate, cocaine and cannabis addiction. It focuses on the period when drug use was first constructed as a delinquency, and thus as a social problem requiring immediate intervention. It examines attempts of physicians and pharmacists to restrict and control drug production, distribution and sale; sanitary propaganda and other prophylactic measures; and the establishment of special institutions for the treatment of addicts. It is concerned only peripherally with the judicial prosecution of drug dealers and drug addicts.

Keywords: drug addiction, public health, late Imperial Russia, early Soviet Russia, opiates, cocaine.

\section{Наркомания и практика здравоохранения в позднеимперской и раннесоветской России}

\section{П. А. Васильев}

Для цитирования: Vasilyev P.A. Drug Addiction and the Practice of Public Health in Late Imperial and Early Soviet Russia // Вестник Санкт-Петербургского университета. История. 2018. Т. 63. Вып. 4. С. 1100-1119. https://doi.org/10.21638/11701/spbu02.2018.407

За относительно короткий период с 1914 по 1932 г. в отношении как правительственных организаций, так и профессиональных сообеств к наркотикам и наркомании

Pavel A. Vasilyev - PhD, Postdoctoral Fellow, Van Leer Jerusalem Institute, 43, Jabotinsky str., Jerusalem, 9104001, Israel; pavelv@vanleer.org.il

Павел Андреевич Васильев - канд. ист. наук, постдокторант, Институт ван Лир в Иерусалиме, Израиль, 9104001, Иерусалим, ул. Жаботински, 43; pavelv@vanleer.org.il

The article was prepared within the framework of the Gerda Henkel Foundation grant AZ 34 / P / 11.

(c) Санкт-Петербургский государственный университет, 2018 
произошли радикальные изменения. До Первой мировой войны подданные Российской империи могли легко купить кокаин или героин в аптеке, а медицинская наука не считала наркоманию серьезной социальной проблемой. Государственное регулирование и законодательство, касающееся наркотиков и наркомании, практически отсутствовало. К началу 1930-х годов, напротив, рынок наркотиков был жестко зарегулирован, торговля наркотиками криминализована, а врачи и криминологи стали клеймить наркоманов как «буржуазных», «дегенеративных» или «социально аномальных» людей, которые подлежат отправке в специальные лагеря. Важной поворотной точкой стал конец 1924 г., когда советские власти издали два декрета, давших правовое определение торговле наркотиками, и подали сигнал к более интенсивной борьбе с наркотизмом. В данной работе рассматривается социальная практика позднеимперского и раннесоветского здравоохранения и дается оценка эволюции врачебных подходов к зависимости от опиоидов, кокаина и каннабиса. Основное внимание уделяется периоду, когда употребление наркотиков впервые было определено как «отклоняющееся поведение». Рассматриваются попытки врачей и фармацевтов ограничить и контролировать производство, распространение и продажу наркотиков, санитарно-пропагандистские и иные профилактические меры, а также работа специализированных учреждений для лечения наркоманов. В меньшей степени затрагиваются вопросы судебного преследования продавцов наркотиков и наркоманов. Основной акцент сделан на эволюции медицинских подходов к предотвращению и лечению наркомании на примере крупного городского центра европейской части России - Санкт-Петербурга-Петрограда-Ленинграда. Работа основывается на документах органов здравоохранения, медицинских, научных и образовательных учреждений из нескольких архивов СанктПетербурга. Многие документы ранее не были использованы историками и фактически впервые вводятся в научный оборот.

Ключевые слова: наркомания, здравоохранение, позднеимперская Россия, раннесоветская Россия, опиаты, кокаин.

In 1914-1932, Russia experienced a series of radical changes, including but not limited to the First World War, the collapse of the Romanov imperial system, the Bolshevik revolution, and the Russian Civil War. Audacious socialist experiments and radical utopian projects characterize this period, as does increasing government regulation ${ }^{1}$. Drug addiction also emerged as a specific social problem during this period; the First World War is widely perceived as an important catalyst worldwide ${ }^{2}$. Scholars have noticed a trend towards the "democratization" of drug addiction, in other words, the "contamination" of previously "clean" social groups, including workers, soldiers, sailors and so forth ${ }^{3}$. Perhaps even more importantly, Russian society after the Great War confronted a dramatic increase in the number of drug addicts, especially among children, teenagers and young people.

A relatively short period from 1914 to 1932 also witnessed a radical change in the attitudes of both governmental authorities and professional communities towards drugs and addiction. Before the First World War, Russians could easily buy cocaine or heroin at a pharmacy, medical science did not view addiction as a serious social problem. There was

${ }^{1}$ On already increasing government regulation of the economy during the last years of Imperial regimes, see: Kitanina T. M. Rossiia v pervoi mirovoi voine 1914-1917 gg.: Ekonomika i ekonomicheskaia politika. St. Petersburg, 2003.

${ }^{2}$ Lisovskii V. T., Kolesnikova E. A. Narkotizm kak sotsial'naia problema. St. Petersburg, 2001. P. 24.

3 Lebina N.B. Povsednevnaia zhizn' sovetskogo goroda: Normy i anomalii: 1920-1930 gody. St. Petersburg, 1999, P.29; Shkarovskii M. V. "Sem' imen "koshki”: Rastsvet narkomanii v 1917-1920-e gody // Nevskii arkhiv: istoriko-kraevedcheskii sbornik. Iss. 3. St. Petersburg, 1997. P. 467. 
practically no government regulation or legislation concerning recreational drugs. By the early 1930s, however, the market of recreational drugs had been heavily regulated, drug sale had been criminalized, and physicians and criminologists had begun to label drug addicts as bourgeois, degenerate, or otherwise socially anomalous people who should be sent to special camps. An important turning point occurred in late 1924, when Soviet authorities issued two decrees that provided a legal definition of criminal drug sales, signaling the start of a more intensive struggle against drug abuse.

Quite surprisingly, no major study has sought to explain the puzzling change in attitudes between 1914 and 1932. The topic remains largely unexplored, even though several authors have briefly discussed the developments of the period. For some obvious reasons, Soviet historiography largely ignored the history of drug addiction in $20^{\text {th }}$ century Rus$\mathrm{sia}^{4}$. New authors interested in drug addiction have emerged since the late 1980s, but the historical picture that they have tried to reconstruct remains mostly fragmentary. Many scholars have published articles and book chapters that at least touch upon the social history of drug addiction in Russia ${ }^{5}$, but there is no major contribution from the perspective of the history of medicine ${ }^{6}$. Perhaps even more importantly, most studies have essentially confined themselves to the narrow period between 1917 and the early 1920s, neglecting both the emergence of social problems during the First World War and the decline of cocaine and opiate addiction in the late 1920s.

Additionally, contemporary historiography focuses largely on legal changes and the role of law enforcement in fighting drug addiction. Such works retain a rather essentialist

${ }^{4}$ For a critique of Soviet Marxist historiography with its tendencies to mythologize and conceal, see: Goriacheshnyi i triumfal'nyi gorod": Petrograd: ot voennogo kommunizma k NEPu: Dokumenty i materialy / ed. by M. V. Khodiakov. St. Petersburg, 2000. P.11-12; Lebina N. B. O pol'ze igry v biser: Mikroistoriia kak metod izucheniia norm i anomalii sovetskoi povsednevnosti 20-30-kh godov // Normy i tsennosti povsednevnoi zhizni: Stanovenie sotsialisticheskogo obraza zhizni v Rossii, 1920-30e gody / ed. by T. Vihavainen. St. Petersburg, 2000. P. 7; Musaev V.I. Prestupnost' v Petrograde v 1917-1921 gg. i bor'ba s nei. St. Petersburg, 2001. P.5.

${ }^{5}$ Popov V.A. Bor'ba s narkomaniei i toksikomaniei detei i podrostkov v 20-30-e gody // Sovetskoe zdravookhranenie. 1989. N. 5. P.67-70; Shkarovskii M. V. Leningradskaia prostitutsiia i bor'ba s nei v 1920-e gody // Nevskii arkhiv: istoriko-kraevedcheskii sbornik. Iss. 1. Moscow, 1993. 1. P.387-411; Lebina N.B. Tenevye storony zhizni sovetskogo goroda 20-30-kh godov // Voprosy istorii. 1994. N 4. P.30-42; Lebina N.B. Narkoman iz narkomata i klub morfinistov revoliutsionnogo Baltflota // Vechernii Peterburg. 12 April 1996; Lebina N. B. Belaia feia, ili Kak "navodili marafet" v Sovetskoi Rossii // Rodina. 1996. N 9. P. 64-66; Shkarovskii M. V. Sem' imen "koshki...; Lebina N. B. Povsednevnaia zhizn'...; Musaev V. I. Prestupnost' v Petrograde...; Lebina N. B., Chistikov A. N. Obyvatel' i reformy: Kartiny povsednevnoi zhizni gorozhan v gody nepa i khrushchevskogo desiatiletiia. St. Petersburg, 2003. See also: Lebina N. B., Shkarovskii M. V. Prostitutsiia v Peterburge: (40-e gg. XIX v. - 40-e gg. XX v.). Moscow, 1994.

${ }^{6}$ Naturally, there are numerous books on the history of relevant medical and research institutions written by medical historians (e.g., Tochilov V.A. and others. Kafedra psikhiatrii i narkologii // Sankt-Peterburgskoi gosudarstvennoi meditsinskoi akademii im. I. I. Mechnikova 90 let. St. Petersburg, 1997. P.99-106; Shabrov A. V., Romaniuk V.P. Bol'nitsa Petra Velikogo - klinicheskaia baza Sankt-Peterburgskoi gosudarstvennoi meditsinskoi akademii imeni I. I. Mechnikova. Vol. 1 (1903-1945). St. Petersburg, 2001; Shabrov A. V., Romaniuk V.P. Sankt-Peterburgskaia gosudarstvennaia meditsinskaia akademiia imeni I. I. Mechnikova. Vol. 1. St. Petersburg, 2006; and especially Akimenko M. A., Shereshevskii A. M. Istoriia instituta im. V. M. Bekhtereva na dokumental'nykh materialakh]. In 3 vol. St. Petersburg, 1999-2001; Akimenko M. A.: Razvitie psikhonevrologii v Institute im. V. M. Bekhtereva v XX veke. St. Petersburg, 2005; Institut imeni V. M. Bekhtereva: ot istokov do sovremennosti (1907-2007). St. Petersburg, 2007). However, these works are often characterized by factual and other errors, have little critical treatment of primary sources, and in the end do not produce any serious theoretical generalizations other than the grand narrative of the respective institution's successful development throughout the turbulent $20^{\text {th }}$ century. 
understanding of drug addiction as an unequivocal social problem to be "solved" through government intervention. Such an approach neglects the existence of diverse regimes of drug prohibition throughout history. The decision to prohibit or legalize this or that psychoactive substance, whether alcohol, marijuana or cocaine, depends on arbitrary historical conditions, not the actual degree of psycho-physical harm or addictiveness ${ }^{7}$. Two important exceptions can be found in works by Mary Schaeffer Conroy and Alisher Latypov $^{8}$. Both scholars reject essentialist understanding of drug addiction, pay close attention to medical texts as primary sources, and focus on a larger chronological period. However, both generally concentrate on theoretical constructions of drug addiction in medical texts, neglecting the practice of drug control and addiction treatment. In addition, Latypov focuses strongly on Central Asia, a region that, while important, is peripheral to our concerns.

Understanding the transformation of Russian attitudes toward psychoactive substances is further complicated by the fact that the most basic terms used to describe "drugs" and "addiction" were subject to constant negotiation and re-definition in the period under discussion ${ }^{9}$. In the early $20^{\text {th }}$ century there was no unanimity about whether substances such as tea, coffee and tobacco were "drugs" 10 . The Russian terms to describe such substances, such as iady, narkotiki, or durmany, were also hotly debated ${ }^{11}$. Medical experts also disagreed about whether to describe the resulting medical problems as narkomaniia, narkotizm, or as more specific conditions such as morfinizm, kokainizm and so forth ${ }^{12}$. A contemporary observer Aleksander Sholomovich spoke of the "horrific spread of cocaine, ether and morphine addiction"13, but ether was, in fact, a rather minor drug in Russia, while opium, heroin and cannabis, which Sholomovich failed to mention, were very widely used. Nevertheless, cocaine, opiates and hashish can still be singled out, since Russian society first experienced the abuse of these drugs as a serious social problem only after the Great War. The use and abuse of alcohol, tobacco, tea and coffee have much longer histories in Russia. For the purposes of this paper, therefore, I adhere to the contemporary understanding that the term "drugs" includes cocaine, opiates, hashish, and ether

${ }^{7}$ Friedman M. Foreword // After Prohibition: An Adult Approach to Drug Policies in the $21^{\text {st }}$ Century / ed. by T. Lynch. Washington, 2001. P. vii.

8 Conroy M. S.: Abuse of Drugs other than Alcohol and Tobacco in the Soviet Union // Soviet Studies. 1990. Iss. 42. P. 447-480; Drug Use and Abuse in Tsarist Russia // M. S. Conroy. In Health and in Sickness: Pharmacy, Pharmacists and the Pharmaceutical Industry in Late Imperial, Early Soviet Russia. Boulder, 1994. P. 200-218; Soviet Pharmaceutical Business During It First Two Decades (1917-1937). New York, 2006; Latypov A.: Central Asian tabibs in post-Soviet archives: Healing, spying, struggling, and 'exploiting' // Wellcome History. 2001. Iss. 43. P. 8-9; Healers and psychiatrists: The transformation of mental health care in Tajikistan // Transcultural Psychiatry. 2010. Iss. 47, N 3. P.419-451; The Soviet doctor and the treatment of drug addiction: "A difficult and most ungracious task // Harm Reduction Journal. 2011. Iss. 8, N 32.

9 About a half-successful attempt to resolve the existing contradictions, see: Lisovskii V. T., Kolesnikova E. A. Narkotizm kak sotsial'naia problema... P. 12.

${ }^{10}$ Concerning a perspective that combines cocaine with tea, coffee and beer, but excludes heroin, see: Sholomovich A.S. Narkotizm kak sotsial'no-patologicheskoe iavlenie i mery bor'by s nim sredi rabochikh // Voprosy narkologii: Sbornik. N 1 / ed. by A.S. Sholomovich. Moscow, 1926.

11 Regarding a critical treatment of poison/medicine contradiction in the history of addiction research, consider Lindesmith A. R., Gagnon J. H. Anomie and Drug Addiction // Anomie and Deviant Behaviour: A Discussion and Critique / ed. by M. B. Clinard. London, 1964. P. 162-163.

12 Cf. internal definitional inconsistencies in the major soviet edited collections voprosy narkologii: voprosy narkologii: sbornik. N 1; Voprosy narkologii: sbornik. N 2 / ed. by A.S. Sholomovich. Moscow, 1928.

13 Sholomovich A. S. Narkotizm kak sotsial'no-patologicheskoe iavlenie... P. 49. 
but not coffee, despite the limitations and implications of this approach for the analysis of medical texts.

Late Imperial medical and criminological texts repeatedly linked drug addiction to decadence and "degeneration," both physical and mental. Both were closely associated with civilization, technological progress, free-market capitalism, urbanization and secularization $^{14}$. This tradition was developed further in the early Soviet period, when drug addiction was constructed as a social problem related to modernity and capitalism, and thus alien to the socialist system ${ }^{15}$. The "democratization" of drug addiction led physicians to differentiate between full-fledged "drugs" on the one hand, and "minor" poisons, such as alcohol and tobacco, on the other. Nevertheless, the statistical data available show that alarmism about an "epidemic" of cocaine addiction should be treated skeptically. Alcohol remained the drug of choice in Russian cities, even during the 1914-1925 period of vodka prohibition. The physicians' reaction to the drug problem was largely inadequate to the scale of the problem and often took the form of a "moral panic," which contributed to the potentially dangerous politicization of cocaine and opiate addiction ${ }^{16}$. Despite the existing alternatives, the majority of physicians eventually supported active government interference and regulation in the drug market ${ }^{17}$.

Apart from large-scale social projects, however, physicians also discussed medical solutions. Given the poor financial situation, unwieldy bureaucracy and inadequately trained medical personnel, several solutions proposed by physicians concerned medical propaganda, sanitary education and prophylaxis. Many Soviet doctors declared the necessity of propagandizing healthy lifestyles, especially through popular books, newspapers and films ${ }^{18}$. David Futer, for example, complained that "there are no special films, slides, fiction books on sanitary education and particularly about the dangers of drugs made for children and teenagers" 19 . Other authors advocated special laboratories and libraries, or the introduction of free-of-charge consultations ${ }^{20}$, particularly emphasizing the impor-

14 Danillo S. N. O vliianii nekotorykh iadov (spirt, opii, gashish) na soznanie u cheloveka. St. Petersburg, 1894; Reimer N.K. Iady tsivilizatsii. St. Petersburg, 1899; Otchet o doktorskom dispute N. N.Lange // Rossiiskaia psikhologiia: Antologiia / ed. by A. N.Zhban. Moscow, 2009. P. 474-515.

15 See, e.g.: Aronovich G.D. Nabliudeniia i vpechatleniia sredi kokainomanov // Nauchnaia meditsina. 1920. Vol.6. P.676-685; Semashko N. A. O kokainizme i bor'be s nim // Izvestiia TSIK SSSR. 1925. Jan. 4 ; Sholomovich A.S. Narkotizm kak sotsial'no-patologicheskoe iavlenie...; Rapoport A. M. Kokainizm i prestupnost' // Moskovskii meditsinskii zhurnal. 1926. N 1. P.46-55; Golant R. Ia. Problemy morfinizma: (Klinicheskie i dispansernye nabliudeniia, eksperimental'nye issledovaniia) // Trudy gosudarstvennogo instituta meditsinskikh znanii (GIMZ). Iss. 5 / ed. by N. K. Rozenberg. Leningrad, 1929. P. 17-32.

16 Lebina N. B. Tenevye storony... P. 30.

17 Concerning a detailed discussion, see: Vasilyev P.: Modernity, Jewishness and Addiction Research in Late 19th and Early $20^{\text {th }}$ Century Russia and Germany // Jewish Studies at the CEU. 2011. Vol. VI. P. 107118; Evoliutsiia predstavlenii o narkotikakh v rossiiskikh meditsinskikh tekstakh (1890-1930-e gody): Ot 'iadov tsivilizatsii' k 'perezhitkam kapitalizma' // Biulleten' Germanskogo istoricheskogo instituta v Moskve. 2012. N 6. P. 53-65; Medical Science, the State, and the Construction of the Juvenile Drug Addict in Early Soviet Russia // Social Justice: A Journal of Crime, Conflict, and World Order. 2012. Vol.38, N 4. P.31-52.

18 Semashko N. A. O kokainizme i bor'be...; Ziman R. M. O kokainizme u detei // Voprosy narkologii: sbornik. N 1. P.30.

19 Futer D.S. O detiakh-narkomanakh // Moskovskii meditsinskii zhurnal. 1925. N 10. P.62-63. Cf. also other problems of popular medical propaganda: Tsentral'nyi gosudarstvennyi arkhiv Sankt-Petersburga (TSGASPb). F.3215. Op. 1. D.307. L. 129.

20 Sholomovich A.S. Narkotizm kak sotsial'no-patologicheskoe iavlenie... P. 49-50. 
tance of preventive campaigns for high risk groups, such as children, youth, criminals and the homeless (besprizorniki) ${ }^{21}$.

Almost every work on the subject discussed establishing special drug clinics (dispansery) for addicts, specifically referring to American and Western European experience in this area ${ }^{22}$. Nikolai A. Semashko, Peoples' Commissar of Public Health, planned to establish such clinics in large cities, assigning them various "medical, educational and inspectorial" tasks and highlighting the success of similar institutions in the struggle against tuberculosis and sexually transmitted diseases ${ }^{23}$. He envisaged that such institutions would have the right to intervene in the personal lives and professional careers of the patients. In another article, David Futer described the practical tasks facing clinics simply as to "catch and heal child addicts" 24 .

This paper examines the social practice of late Imperial and early Soviet public health in order to evaluate the evolution of "in-the-field" medical approaches towards opiate, cocaine and cannabis addiction. It focuses on the period when drug use was first constructed as a delinquency, and thus as a social problem requiring immediate intervention. It examines attempts of physicians and pharmacists to restrict and control drug production, distribution and sale; sanitary propaganda and other prophylactic measures; and the establishment of special institutions for the treatment of addicts. It is concerned only peripherally with the judicial prosecution of drug dealers and drug addicts.

Cocaine and opiate addiction was primarily an urban phenomenon, and, as Valentina B. Zhiromskaia has noted in her study of early Soviet cities, urban social structures were much more complex, dynamic and controversial than those in rural areas ${ }^{25}$. Nataliia B. Lebina has argued that for Russia St. Petersburg/Petrograd/Leningrad has always been something of a "deviant" and "ambivalent" city, and, as such, it presents an advantageous location for the study of "norms" and "anomalies" 26 . Accordingly, my paper seeks to establish a nuanced local picture of the evolution of medical treatment of drug addiction, rather than trying to construct a model of drug abuse in early Soviet Russia on a national scale ${ }^{27}$.

${ }^{21}$ Futer D. S. O detiakh-narkomanakh... P.61; Rapoport A. M. Kokainizm i prestupnost'... P. 48, 55; Kutanin M.P. Voprosy teorii i praktiki morfinizma // Trudy pervogo vsesoiuznogo s"ezda nevropatologov i psikhiatrov / ed. by V. A. Beliaev. Moscow, 1929. P. 40.

22 Bliumenau E. B. Okhmeliaiushchie durmany: Tabak, kokain, morfii, opii, efir i gashish, ikh vred i posledstviia. Leningrad, 1925. P. 61; Ziman R. M. O kokainizme u detei... P. 31; Sholomovich A. S. Narkotizm kak sotsial'no-patologicheskoe iavlenie... P. 48; Gorovoi-Shaltan V.A. Morfinizm, ego rasprostranenie i profilaktika // Voprosy narkologii: Sbornik. N 2. P. 52-53; Dubrovich G. Klinicheskaia kartina kokainizma v detskom vozraste // Voprosy narkologii: Sbornik. N 2. P.74; Sholomovich A.S. Teoriia i praktika bor'by s narkotizmom: tezisy po narkologii dlia medikov. Moscow, [S. a.]. P. 3-4; Bakhtiiarov V.A. K voprosu o narkomanii // Trudy nauchno-issledovatel'skikh institutov Sverdlovskogo oblzdravotdela: Sbornik. N 7. Sverdlovsk, 1936. P. 199.

${ }^{23}$ Semashko N. A. O kokainizme i bor'be... Cf. also argumentation for the establishment of drug clinics on the local and district [raion] level: TSGASPb. F. 3215. Op. 1. D. 306. L. 1-2, 12, 29g; TSGASPb. F. 3215. Op. 1. D. 307. L. 130. The raion principle of organization corresponded nicely to Leningrad physician Nikolai Tutolmin's idea of organizing struggle against addictions from the grassroots (TSGASPb, F. 4301, Op. 1. D. 3414. L. 2-2rev).

24 Futer D. S. O detiakh-narkomanakh... P. 62.

25 Zhiromskaia V.B. Sovetskii gorod v 1921-1925 gg.: problemy sotsial'noi struktury. Moscow, 1988. P. 4 .

26 Lebina N. B. Povsednevnaia zhizn'... P. 16-17.

27 For an example of such an ambitious attempt, consider Stanislav E. Panin's short article: Panin S. E. Potreblenie narkotikov v Sovetskoi Rossii (1917-1920-e gody) // Voprosy istorii. 2003. N 8. P. 129-134. Conroy's 1990 article is a much more detailed work, but it is also bound to provide a broad overview and 
A case study examining one major Russian city, this paper draws on previously unknown sources found in several St. Petersburg archives.

The paper specifically draws on documents from public health, medical, research and educational institutions, supplemented with popular medical literature. I have used the materials of the Central State Archive of St. Petersburg (TSGASPb), the Central State Archive of Scientific and Technical Documentation of St. Petersburg (TSGANTDSPb), the Archive of I. I. Mechnikov North-Western State Medical University (formerly I. I. Mechnikov St. Petersburg State Medical Academy), and the Bekhterev Museum of V. M. Bekhterev St. Petersburg Psychoneurological Research Institute. A substantial portion of these materials has not been previously researched, particularly those concerning the organization of pharmaceutical control and the struggle against "social diseases" during the mid- to late 1920s. Nevertheless, most available archival material consists of official documents from local Soviet institutions, sources which have certain limitations and require a critical attitude ${ }^{28}$. Archival documents record the sale and abuse of drugs in much less detail than other "negative social phenomena" of the period, such as crime, child homelessness, alcohol abuse, prostitution, sexually transmitted diseases, tuberculosis and so on. Drug addiction is almost always discussed with strong pejorative connotations ${ }^{29}$.

\section{A Gray Market: \\ Public Health and Drug Distribution}

While existing scholarship on the history of drugs in late Imperial and early Soviet Russia generally accepts the contemporary image of a "black market" for drugs $\mathrm{s}^{30}$, cocaine and morphine were in fact semi-legal "gray market" substances during that period. The everyday practice in many areas of public health (especially dentistry, ophthalmology, otorhinolaryngology and gynecology) greatly depended on the use of these substances as medicines. Not until the late 1920s did it gradually become possible to reduce the use of these drugs in the practice of public health.

Contemporaries perceived the permissive trade in drugs as a factor contributing to their misuse. They specifically targeted private clinics and pharmacies, irresponsible state-employed doctors/pharmacists and foreign trade. Nevertheless, there was a general feeling that the causes of drug addiction were closely linked to the lack of strict control over import, distribution and sale of recreational drugs ${ }^{31}$. In 1917-1918, for example, private pharmacies, then being phased out, provided a major source of cocaine. Subsequently, cocaine was frequently sold at state pharmacy depots, hospitals and pharmacies ${ }^{32}$.

contain several factual errors by attempting to cover the whole territory of the Soviet Union and a time span of more than 70 years.

${ }^{28}$ Cf., e.g., Deviantnost' i sotsial'nyi kontrol' v Rossii (XIX-XX vv.): Tendentsii i sotsiologicheskoe osmyslenie / ed. by Ia. I. Gilinskii. St. Petersburg, 2000. P. 47.

29 Cf. also: Lebina N. B. Povsednevnaia zhizn'.. P. 28.

30 Such perception is apparently borrowed from the contemporary world where state-funded 'Wars on Drugs' are fought in most countries, the markets for recreational drugs are heavily regulated, and moral panics related to drugs are launched from time to time by physicians and the media.

31 Cf. TSGASPb. F.2815. Op.1. D.526. L. 40 rev.; Semashko N.A. O kokainizme i bor'be...; Bliumenau E.B. Okhmeliaiushchie durmany... P.61-62; Voprosy narkologii: Sbornik. no. 1. P.88, 90; Gorovoi-Shaltan V.A. Morfinizm, ego rasprostranenie.... P. 51-52.

32 TSGASPb. F.2815. Op. 1. D. 526. L. 40 rev. 
The association of morphine with the medical profession was especially strong, even though awareness of its addictive qualities had emerged as early as the $1870 \mathrm{~s}^{33}$. Morphine was widely used in the practice of public health as an excellent painkiller. Naturally, demand increased dramatically during the First World War, not only in Russia, but around the globe. Morphine was frequently prescribed to soldiers with serious injuries, and many became addicted. Furthermore, a substantial number of physicians and nurses, trying to overcome nervous strain and psychological shock, and overconfident in their ability to control their drug use, also became addicts ${ }^{34}$.

Morphine was widely distributed through the national network of hospitals and pharmacies, and it was quite common for drug addicts to obtain morphine with forged prescriptions ${ }^{35}$. Ernst Joël has famously asserted that in wartime conditions "the prescription of opiates ... was less restrained than in the time of peace ... Medical-legal supervision ... was not strict enough, and the persons entrusted [with the storage of drugs] were not careful enough while giving away these medicaments" 36 . There are numerous recorded cases of doctors taking drugs during the Great War and the early Soviet period ${ }^{37}$. Nearly every medical institution had some morphine addicts during the war ${ }^{38}$, several of whom had connections to medical professions ${ }^{39}$. For example, statistics from the Military-Medical Academy in Petrograd for the years 1919-1922 show that almost a half of the addicts were physicians, nurses, medical students, or members of their respective families ${ }^{40}$.

\section{Medical approaches to drug addiction during the last years of the Imperial regime}

Scholars have noticed that neither government authorities nor professional communities perceived drug addiction as a serious social problem in the late Imperial period ${ }^{41}$. Official control over drug distribution and use posed practical difficultiessince there was then no legal definition of criminal drug sale. Certain psychoactive substances were indeed regulated, including cocaine, morphine, opium, ether, heroin, and extract of Indian hemp, and some administrative rules governed their storage and distribution at pharmaceutical institutions. Nevertheless, the rationale behind such laws had more to do with

${ }^{33}$ Cf. a detailed German work on the subject: Gossmann J. Über chronischen Morphiummissbrauch // Deutsche Medicinische Wochenschrift. 1879. P.34-36. See also: Erlenmeier A., Sole P. Morfinizm i ego lechenie. St. Petersburg, 1899.

34 Rapoport A.M. Kokainizm i prestupnost'... P.46; Gorovoi-Shaltan V.A. Morfinizm, ego rasprostranenie... P. 47; Golant R. Ia. Problemy morfinizma... P. 24, 25; Lebina N. B. Povsednevnaia zhizn'... P. 28-29; Petrograd na perelome epokh: Gorod i ego zhiteli v gody revoliutsii i grazhdanskoi voiny / ed. by V.A. Shishkin. St. Petersburg, 2000. P. 93.

35 Cf., e.g., Golant R. Ia. Problemy morfinizma... P. 29.

${ }^{36}$ Joël E. Die Behandlung der Giftsuchten. Alkoholismus, Morphinismus, Kokainismus usw. Leipzig, 1928. S.26-27.

37 See: Bulgakov M. A. Morfii // Bulgakov M. A. Sobranie sochinenii. Ann Arbor, 1982. P.99-129; TSGASPb. F. 4301. Op. 1. D. 2538. L. 250.

38 Panin S.E. Potreblenie narkotikov... P. 130.

39 Shkarovskii M. V. Sem' imen “koshki”... P. 469; Lebina N. B. Povsednevnaia zhizn'.. P. 28; Petrograd na perelome... P.93 etc.

40 Gorovoi-Shaltan V.A. Morfinizm, ego rasprostranenie... P. 47.

${ }^{41}$ Lincoln W. B. In War's Dark Shadow: The Russians before the Great War. New York, 1983. P.351; Lebina N. B. Povsednevnaia zhizn'.. P. 28. 
limiting access to poisons than the recreational use of addictive substances ${ }^{42}$. Criminal responsibility was envisaged only for failure to comply with the rules of drug sale at pharmacies. Punishments were not severe ${ }^{43}$. The absence of government regulation and legislation concerning recreational drugs testifies to the relative scarcity of drug addiction: neither authorities nor society at large saw occasional drug use among certain subjects of the empire as a social problem. Instead, Russian social consciousness understood ether and morphine primarily as poisons. No evidence suggests that the Imperial Russian government felt that it was necessary to fight drug addiction using the Penal Code.

However, as discussed above, the First World War aggravated the problem of drug addiction. Various authorities introduced a number of relevant counter-measures in 1915-1916, but these were largely local, ad-hoc initiatives ${ }^{44}$. The legal understanding of drugs, drug sale and drug addiction remained largely unchanged.

Since drug addiction was not perceived as a major social problem in the Russian Empire, it becomes difficult to analyze what solutions were proposed. As problems generally were identified at the personal level, solutions offered by late Imperial physicians tended to have a narrow focus on individual medical treatment ${ }^{45}$. Following the fin-desiècle trend of "therapeutic pessimism," the majority of late Imperial texts pertaining to the 1914-1917 period have surprisingly little to say even about the practical treatment of drug addiction as an individual condition. They were silent about addiction as a social problem.

\section{Revolutionary medicine fights drug addiction, 1917-1924}

Scholars have traditionally viewed the struggle against drug addiction in the early Soviet period as part of a larger crusade to eliminate the "remnants of capitalism" $46 . \mathrm{Na}$ taliia B. Lebina has distinguished two tendencies in this struggle: "philanthropic, which most physicians adhered to, and punitive, which characterized the representatives of the People's Commissariat for Internal Affairs" ${ }^{\prime 7}$. Lebina acknowledges the interwoven mutual dependency of these two tendencies, yet insists on their utility for historical analysis. Stanislav E. Panin, on the other hand, interpreted the drug policy of Soviet public health institutions as a project of social control ${ }^{48}$. The term "social control" carries some ambigu-

${ }^{42}$ For example, consider : Rossiiskaia Farmakopeia. $6^{\text {th }}$ ed. St. Petersburg, 1910. P. 541-546.

${ }^{43}$ Ulozhenie o nakazaniiakh ugolovnykh i ispravitel'nykh. Ugolovnoe ulozhenie (stat'i, vvedennye v deistvie). Petrograd, 1916. P. 178-179.

${ }^{44}$ Ulozhenie o nakazaniiakh... P. 14-15; Ob uchrezhdenii Glavnogo upravleniia gosudarstvennogo zdravookhraneniia // Sobranie uzakonenii i rasporiazhenii pravitel'stva (hereinafter referred to as SU), 1916. N 252. P. 2448.

45 The situation with alcohol was different. As alcohol addiction already presented a serious social problem at the end of the $19^{\text {th }}$ century and was perceived as such, physicians would often offer various professional (medical), social and cultural proposals that were supposed to eliminate alcoholism.

${ }^{46}$ In theory, deviations were qualified as 'facts of anti-social, anti-socialist behaviour that testify to the existence of non-socialist motives in human consciousness' (Smirnov G. L. Sovetskii chelovek: Formirovanie sotsialisticheskogo tipa lichnosti. $2^{\text {nd }}$ ed. Moscow, 1973. P. 180). For a critique of this artificial division of 'the elements of naturally evolving urban environment' into 'old/capitalist' and 'new/socialist', see: Zhiromskaia V.B. Posle revoliutsionnykh bur': naselenie Rossii v pervoi polovine 20-kh godov. Moscow, 1996. P. 154. On 'remnants of capitalism' see also: Lebina N. B. Povsednevnaia zhizn'... P. 19; Deviantnost' i sotsial'nyi kontrol'... P. 47.

47 Sovetskoe obshchestvo: Vozniknovenie, razvitie, istoricheskii final / ed. by I. V. Afanas'ev. Vol.1. Moscow, 1997. P. 260.

48 Panin S. E. Potreblenie narkotikov... P. 132. 
ity, since deviantologists usually use it to describe social or official reactions to deviant behaviour in general $^{49}$. However, Lebina's "philanthropic" approach also has its difficulties. Lebina herself cites several documents detailing cruel, stigmatizing and abusive treatment of drug-using sex workers in Leningrad clinics, whose patients characterized their time in hospital as "pure torment (odno muchen'e)" 50 .

Strong pharmaceutical control over the production, distribution and sale of drugs characterized the period of the Civil War and War Communism. A raft of legislation regulated the activities of pharmaceutical institutions. In July 1918, the activities of all pharmacies were suspended "in order to fight speculation of various pharmaceutical goods due to their shortage, and also in order to fight medicine forgeries and surrogates and the common practice of illegal sale of medicines harmful for the health of the people" (italics added). The sale of pharmaceuticals was limited exclusively to factories under government control ${ }^{51}$. Such radical measures were abolished on 17 October 1918, and trade resumed, but the sale of strong drugs (sil'nodeistvuiushchie veshchestva) remained in state hands $^{52}$. On 30 December 1918 a further decree transferred control over pharmacies to specially established pharmaceutical subsections of the People's Commissariat of Public Health $^{53}$. While these measures sought to regulate drug distribution and sale and combat drug addiction, forged prescriptions and other abuses of authority remained very common at pharmacies throughout $1918-1921^{54}$.

After the introduction of the New Economic Policy (NEP), the state issued special legal acts to regulate and restrict the activities of emerging private pharmacies seeing them as potential places of illegal drug sale ${ }^{55}$. According to a decree from the Council of People's Commissars of 5 July 1922, "all medicines, produced by cooperatives or individuals can go on sale only with adherence to compulsory regulations regarding the sale of medicaments that are to be set by the People's Commissariat of Public Health in agreement with the Supreme Council of National Economy" ${ }^{56}$. Later, trying to restrict the number of private pharmacies, the People's Commissariat of Public Health demanded that local authorities "be guided by the degree of real necessity of a new institution of such character in the given area" and restrict trade "to those individuals who have the trust of the public health section," with cooperative shops receiving preference ${ }^{57}$. A decree of 13 June 1923 strictly regulated the right of pharmacies to sell cocaine, morphine and opium "in order to achieve fullest accountability ... and prevent possible abuses." Nevertheless, obliging local

49 Gilinskii Ia. I. Sotsiologiia deviantnogo povedeniia i sotsial'nogo kontrolia // Rubezh. 1992. N 2. P. 51-68.

${ }^{50}$ Izmozik V.S., Lebina N. B. Peterburg sovetskii: "novyi chelovek" v starom prostranstve: 1920-1930-e gody: Sotsial'no-arkhitekturnoe mikroistoricheskoe issledovanie. St. Petersburg, 2010. P.120-122, 130, 132.

${ }^{51}$ O regulirovanii prodazhi i otpuska aptekarskikh tovarov // SU. 1918. N 56. P. 665-666.

52 All addictive drugs would be included in this category. See: Rossiiskaia farmakopeia... P.543546; Ob izmenenii "dopolnitel'nogo raz"iasneniia p. 2-go postanovleniia o roznichnoi prodazhe i otpuske aptechnykh tovarov // SU. 1918. N 73. P.904-905.

$53 \mathrm{O}$ natsionalizirovannykh aptekakh, aptechnykh predpriiatiiakh, ob organizatsii upravleniia imi i organakh ikh snabzheniia // SU. 1918. N 100. P. 1290-1291.

${ }^{54}$ Aronovich G. D. Nabliudeniia i vpechatleniia... P. 682.

55 Instruktsiia o prave otkrytiia i proizvodstva torgovli medikamentami // SU. 1922. N 54. P. 874-875.

56 O poriadke proizvodstva medikamentov // SU. 1922. N 43. P.700.

57 O dopolnenii i izmenenii instruktsii o prave otkrytiia i proizvodstva torgovli medikamentami // SU. 1923. N 2. P. 19-20. 
public health sections to perform pharmacy inspections "as often as possible" did not bring any substantive results ${ }^{58}$.

The Pathologo-Reflexological Institute headed by Vladimir M. Bekhterev was primary institution treating drug addicts from 1917 to 1924 in Petrograd / Leningrad . Despite its ambitious design and vision, the institute experienced severe material problems in the early years of the Soviet republic. Until the mid-1920s, treatment was carried out "in conditions of extreme shortages, with a scarcity of medical paraphernalia, poor food provision, often in cold, with an insufficient quantity of medicines". Heating, sewage, electric wiring, and the roof all urgently required repair ${ }^{59}$. In his autobiography, Bekhterev acknowledges that treatment and research during that period were "unprecedentedly handicapped" and recollects that he himself, already a scientist with an international reputation, had to rely for several months exclusively on a diet of oatmeal and low-quality fish (rzhavaia vobla $)^{60}$.

Significantly, the question of how to fight drug addiction remained unanswered. Indeed, during the 1920s doctors still had serious difficulties treating drug addiction as an individual medical condition, let alone as a social problem. Many scientific and pragmatic issues concerning the struggle against drug addiction remained problematic. The treatment of addicts in the hospital would often involve depriving patient of the access to the drug ${ }^{61}$. Physicians expected patients to stay in the clinic for a long time, up to several months, where they were subjected to various forms of treatment, such as hypnosis, psychotherapy $^{62}$, hypodermic oxygen injections ${ }^{63}$, strychnine injections and physiotherapy ${ }^{64}$. The principle of comprehensiveness also required future care for patients even after their formal discharge from the institution.

Monographs, articles and conference presentations by early Soviet physicians were not isolated in a narrow professional realm: physicians actively participated in the elaboration and implementation of state policy on drug addiction. Physicians openly criticized the authorities and actively lobbied communal institutions and governmental agencies for various health improvement schemes in the context of a wider socialist reform ${ }^{65}$. As early as 1920 , Gedalii D. Aronovich noted the possibility that "pernicious devotion to cocaine" might transform into a global "social plague" (sotsial'noe bedstvie); he asked the public (obshchestvennost') and "those who are called to guard social health" to pay close attention to the contemporary type of sniffer (zaniukhannyi) ${ }^{66}$.

The First Scientific Conference on Drug Addiction, held in Moscow in December 1923, found that cocaine abuse was spreading over Soviet Russia like an epidemic ${ }^{67}$. Most

58 O poriadke otpuska i ucheta opiia, kokaina, morphiia i ikh solei // SU. 1923. N 57. P. 1030-1031.

59 Tsentral'nyi gosudarstvennyi arkhiv nauchno-tekhnicheskoi dokumentatsii Sankt-Peterburga (TSGANTDSPb). F.313. Op.1-1. D. 32, 1. 5 rev.

${ }^{60}$ Bekhterev V.M. Avtobiographiia. Moscow, 1928. P. 43.

${ }^{61}$ Bliumenau E. B. Okhmeliaiushchie durmany... P. 61; Kutanin M. P. Voprosy teorii i praktiki... P. 40; Golant R. Ia. Problemy morfinizma... P.31. There were some opponents to the idea, though: Gorovoi-Shaltan V.A. Morfinizm, ego rasprostranenie... P. 51; Trudy pervogo vsesoiuznogo s"ezda... P. 49-50.

62 Bliumenau E.B. Okhmeliaiushchie durmany... P.61; Gorovoi-Shaltan V.A. Morfinizm, ego rasprostranenie... P. 51; Golant R. Ia. Problemy morfinizma...P. 30. TSGASPb. F. 4301. Op. 1. D. 3414, 1. 3 rev.

63 TSGASPb. F. 4301. Op. 1, D. 3414, 1. 3 rev. Cf. also: Bogomolova T. M. Lechenie narkomanov podkozhnym vvedeniem kisloroda // Moskovskii meditsinskii zhurnal. 1925. N 10. P. 40-44.

64 TSGASPb. F. 4301. Op. 1. D. 3414, 1. 3 rev.

${ }^{65}$ Futer D. S. O detiakh-narkomanakh... P. 62; Shkarovskii M. V. Sem” imen "koshki”... P. 474.

66 Aronovich G.D. Nabliudeniia i vpechatleniia.... P. 677-678.

67 Shkarovskii M. V. Sem' imen “koshki”... P. 474. 
importantly, physicians evaluated the various disjointed measures as ineffective and proposed their own plan of action, which the authorities largely implemented in 1925-1929. They called for a struggle against child homelessness (besprizornost') and the closure of known drug dens (pritony) where addicts congregated. The physicians wanted to promote healthy lifestyles through propaganda, establish specialized clinics, organize laboratories and libraries and introduce free-of-charge consultations ${ }^{68}$. Addiction researchers also called for stricter controls over the import and sale of drugs, as well as other economic measures ${ }^{69}$.

\section{Intensification of medical and sanitary influence in 1925-1929}

The government and local public health authorities had implemented most of the measures proposed by medical specialists by the end of the 1920s. The end of 1924 marks a certain chronological boundary because of two important decrees: "On measures for regulating the drug trade" (November 6) and "On adding article 140-d to the Penal Code" (December 22). The former prohibited "the free trade in all strong drugs that can be used for different kinds of intoxication and are detrimental to people's health (cocaine and its salts, opium and its derivatives, such as morphine, heroin etc.)". It regulated the production, import and export of drugs. For the time being, violators were prosecuted under articles 136 and 141 of the Penal Code, which specified rules for trade and state monopolies. The prescribed punishments took the form of prison terms ranging from 6 months to a year ${ }^{70}$.

Article 140-d, introduced in late December, officially punished "production, storage with the aim of sale and sale of cocaine, opium, morphine, ether and other intoxicating substances without proper permission" with a prison term under 3 years. A stronger sentence of no less than three years was specified for the same crime conducted as a business, or for organizing a drug den ${ }^{71}$. Thus, the Soviet government had obviously decided to adopt stricter repressive measures and to set about gradually systematizing relevant legislation: the struggle to eliminate drug addiction was becoming more consistent.

In early January 1925, People's Commissar of Public Health Nikolai A. Semashko published a front-page article in Izvestiia TSIK SSSR, "On Cocaine Addiction and the Struggle Against It"72. Semashko was clearly interested in explaining recent legal developments to a broader audience. He dealt not only with cocaine abuse, but with a variety of other drugs. Semashko claimed that Article 140-d did not punish drug addicts, but instead imposed a penalty upon "the parasite that makes a profit from a morbid predisposition"73. He then demanded various economic and sanitary-educational measures, thus outlining a com-

68 Ziman R.M. O kokainizme u detei... P.293; Sholomovich A.S. Narkotizm kak sotsial'nopatologicheskoe iavlenie... P. 49-50; Voprosy narkologii: Sbornik. N 1. P. 90. Regarding 'sanitary-educational propaganda in artistic design' see also: Futer D. S. O detiakh-narkomanakh... P.62-63.

69 Aleksandr S. Sholomovich even argued that "capitalism is the main cause of drug addiction, because it uses culture as the instrument of greater intoxication" (Sholomovich A.S. Narkotizm kak sotsial'nopatologicheskoe iavlenie... P.47). In fact, Sholomovich's claims can be understood in macroeconomic dimension as the demand to put an end to the NEP. Voprosy narkologii: Sbornik. N 1. P. 89.

70 O merakh regulirovaniia torgovli narkoticheskimi veshchestvami // SU. 1924. N 85. P. 1216-1217.

71 O dopolnenii Ugolovnogo kodeksa stat'ei 140-d // SU. 1925. N 4. P. 58-59.

72 Semashko N. A. O kokainizme i bor'be...

73 Ibid. 
plex programme for fighting drug addiction, which he envisioned would be carried out quickly and completely. Despite the ideologically charged character of Semashko's article, it is clear that in late 1924 and early 1925 central public health agencies managed to gather considerable momentum against drug addiction.

In fact, in the second half of the 1920s stricter controls were imposed on the production, import, circulation and sale of drugs. Archival documents reveal that local authorities in Leningrad quickly took up the central government's initiative. For instance, circular note N.27 from the Leningrad Region Public Health Section (Lengubzdravotdel) on 29 December 1924 required heads of local public health offices, clinics, pharmacy depots and pharmacies to "urgently provide information on the available quantity of ... narcotic drugs," (including cocaine, a stimulant) as of 1 January 1925, and to specify "requests for narcotic drugs necessary until 1 October 1925." The requested documents were promptly supplied, even from hospitals ${ }^{74}$.

The People's Commissariat of Public Health's circular note N.2409 of 18 December 1924, similarly, prescribed rules for distributing, storing and selling drugs and prohibited private companies from producing addictive medicaments after 1 January $1925^{75}$. Lengubzdravotdel, meanwhile, issued its own circular note N. 30 on 14 January 1925, containing "instructions regarding the procedure for receiving, selling, keeping and accounting for such drugs as opium, opium extract, pantopon, cocaine and its salts, morphine and its salts, diacetylmorphine (heroin), hashish and similar drugs (marijuana) etc" ${ }^{16}$. Specific regulations were issued for the sale of drugs from pharmacies subordinate to the regional public health section ${ }^{77}$. In the second half of 1925, further regulations limited drug deliveries from the Administration of Medical Supply and Trade (Gubmedsnabtorg) to chemico-pharmaceutical factories, pharmacies and hospitals ${ }^{78}$. While these documents often lacked any innovative measures, and largely repeated earlier, even pre-revolutionary regulations ${ }^{79}$, their chronological "thickness" indicates that the struggle against drug addiction had also intensified in the medical realm proper.

Contemporaries criticized the new measures as unenergetic and unsystematic ${ }^{80}$, but the intensification of control can indeed be traced through archival documents. For example, the documents from Leningrad public health offices in the Central State Archive of St. Petersburg, specifically, various inspection reports by Lengubzdravotdel employees Gol'dberg and Furman, show that after 1925 the conditions of drug sale from the city's pharmacies were intensively scrutinized ${ }^{81}$. Almost every inspection report contained a list of drug receipts and expenditures, which revealed the wasteful loss of addictive drugs when they exceeded the allowed norm of $4-5 \%^{82}$. These documents often contain critical

74 TSGASPb. F. 4301. Op. 1. D. 1532. L. 105; 111, 134-292, 319-321, 345-345 rev., 347.

75 Ibid. L. 327-328 rev.

76 TSGASPb. F. 4301. Op. 1. D. 1532. L. 117-118.

77 'Responses of pharmacies to the circular note with details of persons responsible for the storage of drugs are presented in: TSGASPb. F. 4301. Op.1. D.1532. L.113-116.

78 TSGASPb. F. 4301. Op. 1. D. 2538. L. 1-2.

79 Rossiiskaia farmakopeia... P. 541-546; O poriadke otpuska... P. 1030-1031.

80 Futer D. S. O detiakh-narkomanakh... P. 62.

81 TSGASPb. F. 3215. Op. 1. D. 276-278, 283-285, 289, 290; TSGASPb. F. 4301. Op.1. D. 729-748, 1519-1527, 1938-1949.

82 TSGASPb. F. 4301. Op. 1. D. 729, L. 174-174 rev.; TSGASPb. D. 733. L. 147-149; TSGASPb. D. 734. L. 185-185 rev.; TSGASPb. D.737. L.62-62 rev.; TSGASPb. D.743. L. 81 rev. - 82; TSGASPb. D. 745. L. 110 rev. - 111; TSGASPb. D.747. L. 49 rev. - 50; TSGASPb. D. 745. L. 122. 
remarks regarding storage of addictive drugs, such as the use of unauthorized weights ${ }^{83}$, the storage of addictive drugs alongside regular ones in an unmarked or unlocked cupboard ${ }^{84}$, and so forth. In some cases, however, the inspectors were completely satisfied with drug storage facilities ${ }^{85}$.

Sometimes inspection reports contain explicit information about illegal drug-related activities at Leningrad pharmacies. For example, inspector Gol'dberg investigated a case in the pharmacy No. 41 at Vera Slutskaia hospital, in which supply pharmacist E. E. Levdikov stole 10 grams of morphine, 25 grams of cocaine and 35 grams of procaine ${ }^{86}$. Another incident concerned a major misuse of drugs at pharmacy N. 35 at the Institute for Maternity and Infancy in June $1925^{87}$.

Intensified pharmaceutical control, however, was only one aspect of the struggle against drug addiction. Large sums of money were also assigned to medical propaganda, sanitary education, and the publication of popular medical literature about the dangers of drugs. Physician Aleksandr S. Sholomovich, for example, painted a bleak picture of cocaine addiction, complete with politicized images of drug dealers and rather hopeless prospects for addicts:

"Dark and unconscious human masses are wandering in the muddy streams of life, looking for the satisfaction of their various necessities; they are met .... by large predators - cocaine smugglers and the network of their agents, who widely cast their nets and baited hooks for the bounty. Ignorant people blindly put their head in the noose, get the alluring little worm, swallow the hook as well and pay ... with the liquors of their body and the energy of a wounded brain ... perhaps, our story can help the ignorant man avoid the cunning hook that he will reach for tomorrow - to avoid the noose of cocaine, which neither a loving family nor a psychiatric hospital can untie"88.

To help save the "ignorant" victims of drug dealers, specialized drug clinics opened in Moscow and Leningrad during the second half of the 1920s. The clinic in Leningrad was founded in September 1926 on the basis of V.M. Bekhterev's Clinical Hospital for Neurotic Patients, the former Pathologo-Reflexological Institute ${ }^{89}$. In March 1927, it was complemented by a permanent Council on the Struggle against Alcohol and Drug Addiction ${ }^{90}$, which included such prominent physicians as Vladimir M. Bekhterev, Raisa Ia. Golant, and Nikolai N. Tutolmin. The tasks of the Council included "discussion and elaboration of alcohol and drug abuse issues for preventive medical initiatives ... participation in the organization of sanitary propaganda in this area ... discussion of the organization of campaign against alcohol and drug abuse"91.

83 TSGASPb. D.729. L. 173.

84 TSGASPb. D. 731 . L. 68 rev.; TSGASPb. D. 733 . L. 145 rev.

85 TSGASPb. D. 734. L. 184; TSGASPb. D. 737. L.61-61 rev.; TSGASPb. D. 743 . L. 81 rev.; TSGASPb.

D. 745. L. 110-110 rev.; TSGASPb. D. 747. L. 49.

86 TSGASPb. F. 4301. Op. 1. D. 729. L. 175.

87 TSGASPb. D.748. L. 186.

88 Sholomovich A.S. Kokain i ego zhertvy: Nauchno-populiarnyi ocherk. Moscow, 1926. P. 4.

89 TSGASPb, F. 4301, Op.1. D.3414. L.33. Cf. also documents on district narcologists, the social diseases division of Lenoblzdravotdel, and the Bekhterev Clinical Hospital: TSGASPb. F.3215. Op.1. D. 304-308, 310; TSGASPb. F. 4301. Op. 1. D. 2482; TSGANTDSPb. F. 313. Op. 1-1. D. 32, 35, 392.

90 Shkarovskii M. V. Sem' imen "koshki”... P. 475.

91 TSGASPb. F.4301. Op. 1. D. 3414. L.6. 
The treatment of drug addicts in Leningrad hospitals, primarily in specialized drug clinics, is naturally an issue of special importance. As mentioned above, treatment was no simple matter. Archival sources reveal, for example, the problems that Russian patients suffering from drug addition faced in the late 1920s: insufficient beds in hospitals, inadequately trained medical personnel, bureaucracy, personal and professional conflicts with administrators, etc ${ }^{92}$. Morphine addict Evgenii N. Kokh, for example, complained to the authorities that he had had to wait for about half a year before being admitted to the drug clinic and had been "in a state of complete incapacity" for one month after receiving some medication - only to be discharged and prohibited from re-entering hospital after a quarrel with another patient (whom he described as "mentally abnormal") and stinging remarks from Golant, the head physician ${ }^{93}$.

Treatment included calcium chloride, special baths and dipsetic food. Drinking lots of fluid caused diuresis, excessive perspiration, and thus eliminated the drug from the patient's body. Depression and irritancy were evident in addicts during the first 3-6 days, and then resumed after 1-2 months for 1-2 weeks. After this period, physicians usually turned to treatments such as hypnosis and psychotherapy; Evgenii V. Bliumenau particularly noted the effectiveness of these new techniques ${ }^{94}$.

For morphine addicts, one problematic issue concerned the speed of withdrawal: should it be gradual or immediate? During 1922-1925, Golant practiced gradual withdrawal of morphine in Leningrad, hoping to soften painful withdrawal symptoms. However, she found gradual withdrawal psychologically just as painful, and turned to immediate withdrawal from 1926. Responding to the new policies of intensified pharmaceutical control, physicians complied with the recommendation to "refrain resolutely" from prescribing any amount of drugs for "non-desperate cases" $"$. They also supported clinical stays lasting as long as several months.

Regarding treatment outcomes, Soviet medical thought during the 1920s found it useful to divide the patients into three groups: (1) occasional users, who had a favourable prognosis, (2) "not full-blown psychopaths" (ne rezko vyrazhennye psikhopaty) whose prognosis was unclear and depended on their social environment since "poverty, desperate unemployment and loneliness" would lead to a relapse, and (3) "severe psychopaths" whose prognosis was nearly hopeless ${ }^{96}$. In any case, more than $36 \%$ of 133 male opiate patients that Golant observed in the clinic in 1925-1929 left the clinic before the end of the treatment, mostly due to improper behaviour or stormy withdrawal symptoms ${ }^{97}$. Taking into account that another $27 \%$ of the patients experienced relapses after 1 to 3 years, we should conclude that, even according to incomplete official statistics, the percentage of cured morphine addicts did not exceed $47 \%$. Even this figure seems suspiciously high, and in fact should be treated with skepticism. Subsequent drug treatment practice during

92 TSGASPb. F. 3215. Op. 1. D. 83. L. 3-4 rev.

93 TSGASPb. F. 3215. Op. 1. D. 83. L. 3 rev.

94 Bliumenau E. B. Okhmeliaiushchie durmany... P. 61.

95 Golant R.Ia. Problemy morfinizma... P.31; Bliumenau E. B. Okhmeliaiushchie durmany... P.61; Kutanin M.P. Voprosy teorii i praktiki... P. 40. Cf. also: Sbornik nevropsikhiatricheskikh rabot, posviashchennyi iubileiu R. Ia. Golant. Leningrad, 1940. P. 13.

96 Rapoport A. M. Kokainizm i prestupnost'... P. 48; Golant R. Ia. Problemy morfinizma... P. 31.

97 Golant R. Ia. Problemy morfinizma.... P.30-31. Golant notes that women were more compliant with the hospital rules, but does not give any figures on their treatment. Women constituted about one-fifth of opiate addicts (Ibid. P. 19). 
the $20^{\text {th }}$ and $21^{\text {st }}$ centuries calls for a more complex approach combining medication, maintenance therapy and relapse prevention. Yet, even in the 1930s such statistics were quietly challenged by other Soviet physicians ${ }^{98}$.

\section{Stalinism and the Treatment of Drug Addiction}

Radical economic and societal changes in the early Soviet period and the liquidation of 'capitalist' NEP by 1930 were certainly greeted by physicians. However, these measures did not manage to eradicate drug addiction fully. The relative ineffectiveness of proper medical treatment, the non-existence of neuroleptics, and the ongoing politicization of cocaine, opiate and hashish addiction led to the introduction of work therapy. In the 1930s, drug clinics evolved first to medical-labor centers and finally - to prison camps under the auspices of the NKVD. In Leningrad, work therapy was first introduced in the late 1920s with a medical-labor center with sewing and hosiery rooms for drug-using sex workers. In the early 1930s, however, the center was transferred to the former premises of AlexanderSvirsky Monastery near Lodeinoe Pole, about 240 kilometers away from Leningrad, under the control of the NKVD. Administrators of prison camps saw addicts as a source of cheap labor and began to use them in timber harvesting and agricultural work under the pretext of work therapy ${ }^{99}$. About the same time, Leningrad Psycho-Neurological Institute, the new name of the Bekhterev Institute, introduced its own hosiery, locksmithery, cobbler's workshop, bookbinder and other shops, as well as an agricultural colony called "Lomaki" in Koporye, about 100 kilometers south-west of the city ${ }^{100}$.

Despite the initial plans to kill two birds with one stone (to economize on the labor force and rehabilitate the addicts), both physicians and camp authorities acknowledged the "extremely low efficiency" and "beastly organization" of these institutions. In medicallabor centers addicts complained that they "are not allowed to go to the city." They continually tried to "run away back to the city" from the "horrifying living conditions" of the former Alexander-Svirsky Monastery ${ }^{101}$.

It should be noted, however, that the focus on work therapy in the treatment of drug addiction was not peculiar to Soviet institutions. Similar procedures also enjoyed popularity in the West. The controversial Federal Medical Center, sometimes known as the Narcotic Farm, was established in Lexington, Kentucky in May 1935. Partly inspired by the ideas of Thomas Kirkbride, it implemented mental health theories about "moral therapy," manual labor in a pastoral setting, and deprivation of external stimuli ${ }^{102}$.

While 'therapeutic pessimism' regarding drug addiction largely prevailed, there was also certain optimistic belief in the possibility of cure with the help of a certain miracle drug or technique. By the 1930s it certainly had become clear that the substitutions of

${ }^{98}$ Kantorovich N. V. Dispansernye nabliudeniia nad morfinistami // Sovetskaia psikhonevrologiia. 1936. Vol.XII, N 3. P. 69-75.

99 Izmozik V. S., Lebina N. B. Peterburg sovetskii... P. 124, 131-132, 134.

100 TSGANTDSPb. F.313. Op.1-1. D.107, 1. 6; Kratkaia istoriia Instituta: K 40-letiiu so dnia osnovaniia. Leningrad, 1948. P. 36.

101 Izmozik V.S., Lebina N. B. Peterburg sovetskii... P. 132, 134.

102 Campbell N.D., Olsen J.P., Walden L. The Narcotic Farm: The Rise and Fall of America's First Prison for Addicts. New York, 2008; Tomes N. The Art of Asylum-keeping: Thomas Story Kirkbride and the origins of American psychiatry. Philadelphia, 1984; Lunbeck E. The Psychiatric Persuasion: Knowledge, Gender, and Power in Modern America. Princeton, 1995. 
morphine for heroin or cocaine (and the other way around) did not work particularly well. However, there were ambitious attempts to introduce other all-curing drugs, as was the case with gravidan - a substance made from the urine of pregnant women and actively promoted by a Moscow doctor Aleksei A.Zamkov (husband of a famous Soviet sculptor Vera I. Mukhina). In particular, Iosif V.Strel'chuk was very enthusiastic about the application of gravidan in the cases of alcoholism and drug addiction. Even though Zamkov's whole idea of 'urogravidanotheraphy' had been largely discredited by the late 1930s, Strel'chuk managed to pursue a successful career in addiction research and continued administration of gravidan well into the 1940s and 1950s ${ }^{103}$.

On the other hand, the practice of addiction treatment also challenges our common notion of the Stalinist period as an epoch of total control and intolerance towards social deviations. In Leningrad, Doctor Nikolai V.Kantorovich practiced continued administration of morphine, heroin and opium to opiate addicts well into the 1930s and observed very positive results. In particular, a certain patient Sh., who used to lead a miserable life of a homeless beggar, was able to find a new job in just a few days after he was accepted in the continued administration program. Moreover, he was later promoted as a residence director in a big dormitory (obshchezhitie) and received bonuses twice. Sticking to his daily dose of heroin, he "became 10 years younger", and even got back in touch with his former wife, who was considering returning to him ${ }^{104}$. In my opinion, such cases broaden and change our understanding of the social history of drug addiction, the history of addiction research and treatment, and the Soviet Union under Stalin in general.

\section{Conclusion}

Despite physicians' efforts and the relatively generous support of their projects on the part of government authorities, drug addiction in Leningrad did not disappear in the 1930s. Marijuana was rather wide-spread, and there were no special regulations regarding this drug until $1934^{105}$. We can also observe cases of drug use in the later period, though obscured by government rhetoric proclaiming the successful eradication of "remnants of the past"106. It should also be noted that the "gray market" situation by and large persisted well into the 1930s. The medical demand for opiates rose in 1939 in Northwestern Russia with the start of the Winter War with Finland, and then across the Soviet Union after the Nazi invasion in June 1941.

Mikhail V.Shkarovskii notes that by the mid-1930s the authorities had largely stopped monitoring the drug situation in the country. The social and psychological features of people prone to drug addiction were ignored; the operations of specialized clinics

${ }_{103}$ Strel'chuk I. V., Obnorskii P.P. Gravidanoterapiia v bor'be s narkomaniei // Biulleten' instituta gravidanoterapii. 1934. N 1. P.37-44; Strel'chuk I. V., Obnorskii P. P., Dudko N. E. et al. Gravidan i problema bor'by s prezhdevremennym odriakhleniem pri alkogol'noi i morfiinoi intoksikatsii // Biulleten' instituta gravidanoterapii. 1935. N 2. P. 42-50; Strel'chuk I. V. Klinika i lechenie narkomanii. $2^{\text {nd }}$ ed. Moscow, 1949. P. 64 .

104 Kantorovich N. V. Dispansernye nabliudeniia... P.73.

105 Lebina N. B. Povsednevnaia zhizn'... P. 46.

106 For example, drug theft from Lenmetallstroi pharmacy in 1935 (TSGASPb. F.7384. Op.2-s. D.60. L.250). Cf. also psychiatry syllabi from the 1930s: Arkhiv Severo-Zapadnogo gosudarstvennogo meditsinskogo universiteta im. I. I. Mechnikova, Nauchnaia chast'. D. 23. L. 20, 23, 35 rev., 36, 39 rev. - 40, 46, 59, 74. See also: Deviantnost' i sotsial'nyi kontrol'... P. 47. 
were suspended. Moreover, by the end of the 1930s, the authorities declared that drug addiction, like prostitution, poverty, child homelessness, and so forth, did not exist in the USSR. During this period, it becomes quite difficult to describe and evaluate the situation regarding drug addiction in Soviet Russia generally, and in Leningrad in particular ${ }^{107}$.

The marginalization and repression of addicts and the politicization of cocaine and opiate addiction contributed to a strong tradition of stigmatizing drug addicts and drug dealers. Negative attitudes persist in Russian society to this day. The government authority to control the drug market goes unquestioned, even though narcotic policies are often costly, bureaucratic and inefficient ${ }^{108}$.

An evaluation of medical anti-drug measures should acknowledge their relative ineffectiveness in the period of 1914-1924. The second half of the 1920s witnessed the gradual intensification as well as qualitative improvement of these measures. Drug addiction was a relatively small and insignificant problem in comparison with other events of this turbulent period, which explains the substantial delay in addressing the drug problem. In the 1920s, a prosecutor in the Leningrad region, I. A. Krastin, commented on this seeming paradox: "Now these things do not pass unnoticed, but did we pay even the slightest attention to them in 1919?" 109 By modern standards, however, the medical measures employed in the late 1920s should be evaluated as largely ineffective ${ }^{110}$.

\section{References}

Akimenko M. A., Shereshevskii A. M. Istoriia instituta im. V. M. Bekhtereva na dokumental'nykh materialakh. Vol. 1. St. Petersburg, SPbNIPNI Publ., 1999, 219 p. (In Russian)

Akimenko M. A., Shereshevskii A. M. Istoriia instituta im. V. M. Bekhtereva na dokumental'nykh materialakh. Vol.2. St. Petersburg, SPbNIPNI Publ., 2000, 294 p. (In Russian)

Akimenko M. A., Shereshevskii A. M. Istoriia instituta im. V. M. Bekhtereva na dokumental'nykh materialakh. Vol.3. St. Petersburg, SPbNIPNI Publ., 2001, 262 p. (In Russian)

Akimenko M. A. Razvitie psikhonevrologii v Institute im. V. M. Bekhtereva v XX veke. Avtoreferat ... doctora med. nauk. St. Petersburg, SPbNIPNI Publ., 2005, 34 p. (In Russian)

Akimenko M. A. Institut imeni V. M. Bekhtereva: ot istokov do sovremennosti (1907-2007). St. Petersburg, Litografiia Publ., 2007, 946 p. (In Russian)

Campbell N.D., Olsen J.P., Walden L. The Narcotic Farm: The Rise and Fall of America's First Prison for Addicts. New York, Abrams Publ., 2008, 208 p.

Conroy M.S. Abuse of Drugs other than Alcohol and Tobacco in the Soviet Union. Soviet Studies, 1990, no. 42 , pp. $447-480$.

Conroy M.S. Drug Use and Abuse in Tsarist Russia. Conroy M.S. In Health and in Sickness: Pharmacy, Pharmacists and the Pharmaceutical Industry in Late Imperial, Early Soviet Russia. Boulder, Columbia University Press, 1994, pp. 200-218.

Conroy M. S. The Soviet Pharmaceutical Business During it First Two Decades (1917-1937). New York, Peter Lang Publ., 2006, 389 p.

Friedman M. Foreword. After Prohibition: An Adult Approach to Drug Policies in the $21^{\text {st }}$ Century. ed. by T. Lynch. Washington, Cato Institute Publ., 2001, 159 p.

107 Shkarovskii M. V. Sem' imen "koshki"... P. 477.

108 For examples of bureaucratic inefficiency from the 1920s, see TSGASPb. F. 3215. Op. 1. D. 305. L. 155, 170, 189-189 rev., 209-211, 224. For a general critique of the government regulation of the drug market, see: Nadelmann E. A. Drug Prohibition in the United States: Costs, Consequences, and Alternatives // Science. 1989. N 245. P.939-947.

109 Khuliganstvo i prestuplenie. Leningrad; Moscow, 1927.

110 Some medical papers of the late 1930s also hinted at this ineffectiveness and even argued for the continued administration of the drug to 'incurable' addicts and some forms of 'harm reduction'. See, e.g.: Kantorovich N. V. Dispansernye nabliudeniia... P. 72-74. 
Gilinskii Ia. I. Sotsiologiia deviantnogo povedeniia i sotsial'nogo kontrolia. Rubezh, 1992, no. 2, pp.51-68. (In Russian)

Izmozik V.S., Lebina N.B. Peterburg sovetskii: "novyi chelovek" v starom prostranstve: 1920-1930-e gody: Sotsial'no-arkhitekturnoe mikroistoricheskoe issledovanie. St. Petersburg, Kriga Publ., 2010, 248 p. (In Russian)

Kitanina T. M. Rossiia v pervoi mirovoi voine 1914-1917 gg.: Ekonomika i ekonomicheskaia politika. Vol. 1. St. Petersburg, St. Petersburg University Press, 2003, 144 p. (In Russian)

Latypov A. Central Asian tabibs in post-Soviet archives: Healing, spying, struggling, and 'exploiting'. Wellcome History, 2010, no. 43, pp. 8-9.

Latypov A. Healers and psychiatrists: the transformation of mental health care in Tajikistan. Transcultural Psychiatry, 2010, iss. 47, no. 3, pp.419-451.

Latypov A. The Soviet doctor and the treatment of drug addiction: "A difficult and most ungracious task". Harm Reduction Journal, 2011, iss. 8, no. 32, pp. 1-19.

Lebina N. B. Belaia feia, ili Kak "navodili marafet" v Sovetskoi Rossii. Rodina, 1996, no.9, pp.64-66. (In Russian)

Lebina N. B. O pol'ze igry v biser: Mikroistoriia kak metod izucheniia norm i anomalii sovetskoi povsednevnosti 20-30-kh godov. Normy i tsennosti povsednevnoi zhizni: Stanovenie sotsialisticheskogo obraza zhizni v Rossii, 1920-30e gody. Ed. by T. Vihavainen. St. Petersburg, Neva Publ., 2000, pp.9-26. (In Russian)

Lebina N. B. Povsednevnaia zhizn' sovetskogo goroda: Normy i anomalii: 1920-1930 god. St. Petersburg, Neva, Letnii Sad Publ., 1999, 316 p. (In Russian)

Lebina N. B. Tenevye storony zhizni sovetskogo goroda 20-30-kh godov. Voprosy istori, 1994, no. 4, pp. 3042. (In Russian)

Lebina N. B., Chistikov A. N. Obyvatel' i reformy: Kartiny povsednevnoi zhizni gorozhan v gody nepa i khrushchevskogo desiatiletiia. St. Petersburg, Dmitrii Bulanin Publ., 2003, 339 p. (In Russian)

Lebina N. B., Shkarovskii M. V. Prostitutsiia v Peterburge (40-e gg. XIX v. -40 -e gg. XX v.). Moscow Progress-Akademiia Publ., 1994, 221 p. (In Russian)

Lindesmith A. R., Gagnon J.H. Anomie and Drug Addiction. Anomie and Deviant Behaviour: a Discussion and Critique. London, The Free Press of Glencoe Publ., 1964, pp. 162-163.

Lisovskii V.T., Kolesnikova E. A. Narkotizm kak sotsialnaia problema. St. Petersburg, St. Petersburg State University Press, 2001, 198 p. (In Russian)

Lincoln W. B. In War's Dark Shadow: The Russians before the Great War. New York, The Dial Press, 1983, $574 \mathrm{p}$.

Lunbeck E. The Psychiatric Persuasion: Knowledge, Gender, and Power in Modern America Princeton, Princeton University Press, 1995, 445 p.

Musaev V.I. Prestupnost' v Petrograde v 1917-1921 gg. i bor'ba s nei. St. Petersburg, Dmitrii Bulanin Publ., 2001, 207 p. (In Russian)

Nadelmann E. A. Drug Prohibition in the United States: Costs, Consequences, and Alternatives. Science, 1989, no. 245, pp.939-947.

Panin S.E. Potreblenie narkotikov v Sovetskoi Rossii (1917-1920-e gody). Voprosy istorii, 2003, no. 8, pp. 129-134. (In Russian)

Petrograd na perelome epokh: Gorod i ego zhiteli v gody revoliutsii i grazhdanskoi voiny. Ed. by V. A. Shishkin. St. Petersburg, Dmitrii Bulanin Publ., 2000, 349 p. (In Russian).

Popov V.A. Bor'ba s narkomaniei i toksikomaniei detei i podrostkov v 20-30-e gody. Sovetskoe zdravookhranenie, 1989, no. 5, pp.67-70.

Shabrov A. V., Romaniuk V.P. Bol'nitsa Petra Velikogo - klinicheskaia baza Sankt-Peterburgskoi gosudarstvennoi meditsinskoi akademii imeni I. I. Mechnikova. Vol. 1 (1903-1945). I. I. Mechnikov St. Petersburg State Medical Academy Press, 2001, 327 p. (In Russian)

Shabrov A.V., Romaniuk V.P. Sankt-Peterburgskaia gosudarstvennaia meditsinskaia akademiia imeni I. I. Mechnikova. Vol.1. St. Petersburg, I. I. Mechnikov St. Petersburg State Medical Academy Press, 2006, 501 p. (In Russian)

Shkarovskii M. V. Leningradskaia prostitutsiia i bor'ba s nei v 1920-e gody. Nevskii arkhiv: istorikokraevedcheskii sbornik, 1993, iss. 1, pp.387-411. (In Russian)

Shkarovskii M. V. "Sem' imen "koshki”: Rastsvet narkomanii v 1917-1920-e gody. Nevskii arkhiv: istorikokraevedcheskii sbornik, 1997, iss. 3, pp. 467-477. (In Russian)

Smirnov G. L. Sovetskii chelovek: Formirovanie sotsialisticheskogo tipa lichnosti. $2^{\text {nd }}$ ed. Moscow, Politizdat Publ., 1973, 415 p. (In Russian) 
Tochilov V. A. Kafedra psikhiatrii i narkologii. Sankt-Peterburgskoi gosudarstvennoi meditsinskoi akademii im. I. I. Mechnikova 90 let. St. Petersburg, I. I. Mechnikov St. Petersburg State Medical Academy Press, 1997, pp. 99-106. (In Russian)

Tomes N. The Art of Asylum-keeping: Thomas Story Kirkbride and the origins of American psychiatry. Philadelphia, University of Pennsylvania Press, 1984, 387 p.

Vasilyev P. A. Evoliutsiia predstavlenii o narkotikakh v rossiiskikh meditsinskikh tekstakh (1890-1930-e gody): Ot 'iadov tsivilizatsii' k 'perezhitkam kapitalizma'. Biulleten' Germanskogo istoricheskogo instituta v Moskve, 2012, no. 6, pp. 53-65. (In Russian)

Vasilyev P. A. Medical Science, the State, and the Construction of the Juvenile Drug Addict in Early Soviet Russia. Social Justice: A Journal of Crime, Conflict, and World Order, 2012, iss. 38, no. 4, pp. 31-52.

Vasilyev P. A. Modernity, Jewishness and Addiction Research in Late $19^{\text {th }}$ and Early $20^{\text {th }}$ Century Russia and Germany. Jewish Studies at the CEU, 2011, vol. VI, pp. 107-118.

Zhiromskaia V.B. Sovetskii gorod v 1921-1925 gg.: Problemy sotsial'noi struktury. Moscow, Nauka Publ., 1988, 167 p. (In Russian)

Zhiromskaia V. B. Posle revoliutsionnykh bur': naselenie Rossii v pervoi polovine 20-kh godov. Moscow, Nauka Publ., 1996, 157 p. (In Russian)

Received: June 9, 2018

Accepted: September 10, 2018 